\title{
The Ethiopian Statutory Rape Law in Light of Human Rights Approach
}

\author{
Enguday Meskele Ashine \\ Lecturer in Human Rights Law and International Law @,Wolaita Sodo University, School of Law, Wolaita Sodo, \\ Ethiopia. P.O. Box 138
}

\begin{abstract}
Statutory rape refers to sexual relations involving someone below the "age of consent." People below the age of consent cannot legally consent to having sex. This means that sex with them, by definition, violates the law. Statutory rape laws vary by state, with states setting the age of consent differently, as well as using different names to refer to this crime. Ethiopian statutory rape provided under laws addressing injury to sexual liberty and chastity. This article will examine the Ethiopian statutory rape law in light of human right approach. During the investigation of the Federal Supreme Court Cassation Division Decision, the constitution of Ethiopian and international human right instruments shows that this statutory provision violate the victims and the defendants human right.
\end{abstract}

Keywords: human right, rape, statutory, sexuality.

DOI: $10.7176 / J L P G / 97-01$

Publication date:May $31^{\text {st }} 2020$

\section{Introduction}

Article 2 of the non-binding UN Declaration on the Elimination of Violence against Women (DEVAW), ${ }^{1}$ which was adopted in 1993 as the first international pronouncement regarding violence against women and is applicable to all member states, states that physical, sexual, and psychological violence in the family, (i.e., domestic violence, marital rape, forced begging by parents), battery, sexual abuse of children (such as sexual intercourse with a female minor, involvement in prostitution, child pornography, statutory rape, rape by male members of the family), dowry-related violence (i.e. early and forced marriages, bride kidnapping), harmful traditional practices like female genital mutilation, rape (this is a non-spousal, committed by a stranger) are violence related to exploitation. ${ }^{2}$ The confluence of the feminist movement and the sexual liberation movement helped to shape the reform of statutory rape laws. The feminists further influenced those reforms by collaborating with law-and-order groups to bring about comprehensive reforms of laws governing criminal sexual misconduct. ${ }^{3}$

The articulated rationale for the offense of statutory rape is that persons below the age of consent lack the maturity and judgment to give sufficiently informed consent, exploitation of experienced sexual predators and to protect from the effect of sexual intercourse. ${ }^{4}$

With regard to rape or sexual outrage against minors, alias "statutory rape", it appears that the criminal code of Ethiopia has given sufficient protection against these acts. ${ }^{5}$ The Age of Consent in Ethiopia is 18 years old. The age of consent is the minimum age at which an individual is considered legally old enough to consent to participation in sexual activity. Individuals aged 17 or younger in Ethiopia are not legally able to consent to sexual activity, and such activity may result in prosecution for statutory rape or the equivalent local law. ${ }^{6}$

Statutory rape is a strict-liability crime which applies with respect to victims' age: in many jurisdictions, the prosecution is not required to prove that the defendant knew that the complainant was under the threshold age of consent. Moreover, a defendant's good-faith mistaken belief concerning the victim's age does not exonerate from criminal liability for statutory rape. ${ }^{7}$

When this law is applied practically we should have to consider the effects that it may have on adolescents and their human rights. This article it will examine that the Ethiopian statutory rape provisions and its practical implementation violates adolescents' human rights. Specifically, it will be said to violate adolescents' right to confidentiality, health, as well as equality and non-discrimination, as recognized both by domestic and international human rights law.

\footnotetext{
${ }^{1}$ U.N. General Assembly, UN Declaration on the Elimination of Violence against Women, U.N. Doc A/RES/48/104 (20 December 1993)[hereinafter 'DEVAW'].

${ }^{2}$ Sevinj Jabrayilova "The Distinctive Features of Sexual-Related Offences: Statutory Rape V. Marital Rape Vol. 9 No. 1 (Summer 2012)," Ankara Law Review pp. 82

${ }_{3}^{3}$ Michelle Oberman, Turning Girls into Women: Re-Evaluating Modern Statutory Rape Law, 85 J. Crim. L. \& Criminology 15 (1994-1995)

${ }^{4}$ Russell Christopher and Kathryn Hope Christopher "The Paradox of Statutory Rape" ttp://ssrn.com/abstract= 2014327

${ }^{5}$ Tsehai Wada "Rethinking the Ethiopian Rape Law" 2012(XXV) Journal of Ethiopian Law p.16.

${ }^{6}$ The Criminal Code of the Federal Democratic Republic of Ethiopia 2004 Article 626-628

${ }^{7}$ Assaf Hamdani "Mens Rea And The Cost of Ignorance" Bar-Ilan University Public Law and Legal Theory Working Paper No. 06-4 (March, 2006), p. 23
} 


\section{Ethiopian Statutory rape law and human right}

Article 395 of the 1930 Penal Code dealt with sexual intercourse with a girl who has not attained the age of puberty, without the consent of her parents. In such cases, the man was punished, regardless of whether or not the girl had consented to the act. ${ }^{1}$ Under the 1957 Penal Code only rape committed "outside wedlock" is punishable under article 589 of the 1957 Penal Code. ${ }^{2}$

The Constitution of Ethiopia recognizes a various human right protection of individuals. Article 35 of the Constitution specifically states that women have equal rights with men in the enjoyment of the rights and protections incorporated into the Constitution. ${ }^{3}$ In addition the constitution affirmed under article 25 provides that:

All persons are equal before the law and are entitled without any discrimination to the equal protection of the law. In this respect, the law shall guarantee to all persons equal and effective protection without discrimination on grounds of race, nation, nationality, or other social origin, color, sex, language, religion, political or other opinion, property, birth or other status. It can be inferred that women are accorded the same rights and entitled to the same protection of rights as men in the Constitution.

Ethiopian criminal code provide under article 626 and 627 prohibit sexual intercourse with or penetration of a juvenile below the age of thirteen or between thirteen and eighteen respectively. ${ }^{4}$

This criminal code provision criminalizes person who undertake sexual intercourse with minor. The law is to protect adolescents from sexual abuse. However, the statutory rape crime is most severely punished under Ethiopian law. Perpetrators may be convicted to up to twenty five years of imprisonment.

Both the above provisions are broad in application and strict it doesn't require the mental element of the offenders. And there difference is on the penalty. The act when committed by a male is punishable with rigorous imprisonment from three years to fifteen years, while it is rigorous imprisonment not exceeding seven years, when it is committed by a female. ${ }^{5}$

Whatever the rational for the difference in punishments it is not in accordance with the constitution of Ethiopia and other international human right instrument since it is unfairly discriminate.

"Rape committed against a young woman between thirteen and eighteen years of age, is an aggravated crime under Art.620 (2) (a); per Art.626(1\&2), sexual outrage with a minor of the opposite sex under the same age bracket is made a crime, though the punishment varies when the act is done by a male and a female; and performing an act corresponding to the sexual act or any other indecent act, as well as, deliberately performing such acts in their presence, against minors in this age group is a punishable act, under Art.626(3). Moreover, per Art.626 (4), the respective punishments are made more sever, when the victim is the pupil, apprentice, domestic servant or ward of the criminal. According to Art.627, all these crimes when committed against minors who are below the age of thirteen are made punishable with more severe penalties, compared to those provided for sexual outrage. At last, per Art.628, unless and otherwise a more severe penalty is provided, the penalty will be aggravated where: the victim becomes pregnant; the criminal transmits to the victim a venereal disease which he knows himself to be infected; or the victim is driven to suicide by distress , shame or despair." ${ }^{\prime 6}$ From this statutory rape vastly incorporated in Ethiopia but still now it need some consideration with regard to human right instruments.

\subsection{The close-in-age exception}

When examining statutory rape law, it is relevant to consider whether a close-in-age exception has been established in the Ethiopian criminal code. In the case of Ethiopia there is no close in age exception which is found in other jurisdiction. Ethiopia statutory rape law is violated when an individual has consensual sexual contact with a person under age 18. However, this law is not usually enforced. Ethiopia does not have a close in age exceptions. Close in age exceptions, commonly known as "Romeo and Juliet laws" in the United States, are put in place to prevent the prosecution of individuals who engaged in consensual sexual activity when both participants are significantly close in age to each other, and one or both partners are below the age of consent. ${ }^{7}$ Because there is no close in age exemption in Ethiopia it is possible for two individuals both under the age of 18 who willingly engaged in intercourse to both be prosecuted for statutory rape. Similarly, no protections are reserved for sexual relations in which one participant is a 17 year old and the second is 18 or `19 year old.

The best known modern statutory rape case in Ethiopia is Bona Ahimed Vs Harary Region Public Prosecutor; ${ }^{8}$ in that case, sixteen-year-old male who had sex with a fifteen-year-old female the Supreme Court convicted him violating article 626(1) of the criminal code. The victim gave her testimony sexual intercourse that happened between them is consensual but the court ruled that the law is to protect the girl under eighteen from sexual abuse

\footnotetext{
${ }^{1}$ Supra note 4 p. 16

21957 Penal Code, article 589

${ }^{3}$ Constitution of the Federal Democratic Republic of Ethiopia Proclamation No. 1/199 article 35

${ }^{4}$ Supra note at 5

${ }^{5}$ Supra note at 5 article $626(1)$ and (2)

${ }^{6}$ Supra note at 5 p. 25

${ }^{7}$ criminal.findlaw.com lastly accessed January 27, 2016, 12:30:27 AM

${ }^{8}$ Bona Ahimed Vs Harary Region Public Prosecutor; Federal Supreme Court Cassation Division Decision volume 12, page 162
} 
whether there is consent or not is irrelevant.

\subsection{Statutory rape law on adolescents' right to equality and non-discrimination}

For the purposes of this article, it is relevant to consider whether age-based discrimination may be considered unlawful. Though "age" is not specifically enumerated as grounds of discrimination by any human rights treaty, it is a factor which may be called upon when establishing differential treatment. Indeed, the Convention on Civil and Political Rights, CRC and CEDAW and the Ethiopian Constitution all have open-ended equality provisions meaning that other grounds of discrimination, such as age, may be invoked.

To consider whether this distinction is unlawful under the Ethiopia Constitution, one must consider the way in which the equality clause is interpreted domestically. As per the Ethiopian constitution all persons are equal before the law and are entitled without any discrimination to the equal protection of the law. In this respect, the law shall guarantee to all persons equal and effective protection without discrimination on grounds of race, nation, nationality, or other social origin, color, sex, language, religion, political or other opinion, property, birth or other status. ${ }^{1}$ Currently, equality is understood as a limit to State powers and as a defense mechanism in cases of arbitrary discrimination. What is specifically prohibited by the Ethiopian Constitution is arbitrary discrimination, understood as an unjustified or unreasonable difference in treatment.

According to general comment of CESCR discrimination against women is "any distinction, exclusion or restriction made on the basis of sex which has the effect or purpose of impairing or nullifying the recognition, enjoyment or exercise by women, irrespective of their marital status, on a basis of equality of men and women, of human rights and fundamental freedoms in the political, economic, social, cultural, civil or any other field" 2

Direct discrimination occurs when a difference in treatment relies directly and explicitly on distinctions based exclusively on sex and characteristics of men or of women, which cannot be justified objectively. ${ }^{3}$

Gender affects the equal right of men and women to the enjoyment of their rights. Gender refers to cultural expectations and assumptions about the behaviour, attitudes, personality traits, and physical and intellectual capacities of men and women, based solely on their identity as men or women.

According to article 626(1) and (2) whoever performs sexual intercourse with a minor of the opposite sex, who is between the ages of thirteen and eighteen years, or causes her / him to perform such an act with her/him, is punishable. The punishment is with rigorous imprisonment from three years to fifteen years for male or with rigorous imprisonment not exceeding seven years for woman.

Ethiopian statutory rape law protects the right of child under age from sexual violence without discrimination on both male and female. Both female and male is prohibited from sexual intercourse with underage the article is gender neutral. However, the penalty clause is not proportional with in both situations. Therefore the criminal code of Ethiopia under statutory rape provisions it violate sexual autonomy of adolescent offenders disproportionately. And the law has no close in age exception to exonerate those consensual sex offenders from criminal liability by way of exception.

The statutory rape provision at hand makes a distinction based on age. That is, it draws a distinction between adolescents under the age of eighteen and those above that age. This distinction consists of denying that anyone below the age of eighteen has the capacity to consent to sexual intercourse. In other words, younger eighteen are not provided with a certain right or service that older than eighteen are provided with.

The distinction in this case is based on "age". This may appear to be an objective criterion. Indeed, it certainly is a convenient way to measure maturity. Nonetheless, a closer look will reveal that "age" is not purely objective. This is so because adolescents of the same age tend to have different levels of maturity. This principle is that of evolving capacities. It is broadly contained in article 5 of the CRC Convention, which establishes that:

"States Parties shall respect the responsibilities, rights and duties of parents or, where applicable, the members of the extended family or community as provided for by local custom, legal guardians or other persons legally responsible for the child, to provide, in a manner consistent with the evolving capacities of the child, appropriate direction and guidance in the exercise by the child of the rights recognized in the present Convention."

Based on this principle, States have the obligation to consider the level of maturity of individuals. This must be done on a case by case basis, as cognitive capacities vary from individual to individual. The high stakes involved in the case of statutory rape, which include criminal prosecution, call for a more flexible norm. Indeed, this legislation, as well as its aim to protect children and adolescents, coincides with a specific image of adolescent sexuality. That is, adolescents are assumed and expected to be ignorant of sexual matters. Such an aim exceeds the limits of legitimacy, denying adolescents' rights and autonomy.

\footnotetext{
${ }^{1}$ Supra note 10 art 25

${ }^{2}$ CESCR, general comment No. 16 (2005): The equal right of men and women to the enjoyment of all economic, social and cultural rights (art.

3 of the International Covenant on Economic, Social and Cultural Rights), paras. 11

${ }^{3}$ Ibid para. 12
} 


\subsection{Gender discrimination}

The traditional image of female sexuality is essentially passive, as girls are seen as victims or objects of desire. Male sexuality, on the other hand, is seen as active, natural and uncontrollable.

Indeed, statutory rape laws generally affect girls.

In the above case Federal Supreme Court Cassation Division decisions fail to distinguish situations where adolescents, including female adolescents, may have chosen to freely engage in sexual intercourse. Reporting in such circumstances leads to the victimization of adolescent girls and, consequently, disempowers them. It sends the message that they are not free to make decisions about their sexuality. Thus, the traditional image of female sexuality is re-enforced. This can be argued to constitute gender discrimination, in the terms set out by CEDAW. ${ }^{1}$

\section{Conclusions}

Generally a statutory rape law purpose is protecting those under certain age from sexual intercourse. This article has attempted to address the effectiveness of the Ethiopian law on statutory rape in fulfilling its declared goal of protecting young adolescents from potential sexual abuse and rape.

A careful analysis has revealed that the provision does not adequately accomplish this goal, as in its attempt to protect it violates adolescents' fundamental human rights. The statutory rape provision lacks proportionality and denies adolescents autonomy, leading, in turn, to the affectation of their human rights.

Also this law restricts privacy right of the adolescents' and exposing them into prosecution through the law or report of the family. We have seen that even if the statutory rape law of Ethiopia is gender neutral the provisions need certain consideration in light with the law of the land and the international human right instruments.

\section{Recommendation}

$>$ I recommend that the Ethiopian criminal code need a reform on statutory rape provisions especially in penalty since disproportionately discriminate male and female.

$>$ Some country have passed so-called "Romeo and Juliet laws," which serve to reduce or eliminate the penalty of the crime in cases where the couple's age difference is minor and the sexual contact would not have been rape if both partners were legally able to give consent. From this practice of other country we should have to share since there is the possibility of higher punishment which is not in line with the rationale for statutory rape crime.

$>$ The legislature should take in to consideration and evaluation of many complex problems and issues whenever enacting statutory rape law for the better implementation.

\section{Reference}

Books

$>$ Tsehai Wada "Rethinking the Ethiopian Rape Law" 2012(XXV) Journal of Ethiopian Law

$>$ Sevinj Jabrayilova "The Distinctive Features of Sexual-Related Offences: Statutory Rape V. Marital Rape Vol. 9 No. 1 (Summer 2012)," Ankara Law Review

$>$ Michelle Oberman, Turning Girls into Women: Re-Evaluating Modern Statutory Rape Law, 85 J. Crim. L. \& Criminology 15 (1994-1995)

$>$ Russell Christopher and Kathryn Hope Christopher "The Paradox of Statutory Rape" ttp://ssrn.com/abstract $=2014327$

$>$ Assaf Hamdani "MENS REA AND THE COST OF IGNORANCE” Bar-Ilan University Public Law and Legal Theory Working Paper No. 06-4

\section{National Laws}

$>$ Constitution of the Federal Democratic Republic of Ethiopia Proclamation No. 1/1995

$>$ The Criminal Code of the Federal Democratic Republic of Ethiopia 2004

\section{International Instruments}

$>$ International Covenant on Economic, Social and Cultural Rights (adopted 16 December 1966, entered into force 3 January 1976) 993 UNTS 3 (ICESCR)

$>$ International Covenant on Civil and Political Rights. Adopted by the General Assembly of the United Nations on 19 December 1966.

$>$ Convention on the Rights of the Child Adopted and opened for signature, ratification and accession by General Assembly resolution 44/25 of 20 November 1989 entry into force 2 September 1990, in accordance with article 49.

$>$ Committee on Economic, Social and Cultural Rights (2005). General Comment 16

\footnotetext{
${ }^{1}$ Convention on the Elimination of All Forms of Discrimination Against Women (CEDAW) (1979). Article 1
} 